\title{
Phytophthora Crown Rot of Strawberry ${ }^{1}$
}

\author{
Natalia A. Peres and Juliana S. Baggio ${ }^{2}$
}

\section{Introduction}

Phytophthora crown rot, caused mainly by Phytophthora cactorum, is an important disease in Florida strawberry fields. On average, about $30 \%$ of the strawberry crown rot samples received in the Plant Diagnostic Clinic located at the UF/IFAS Gulf Coast Research and Education Center (GCREC) are diagnosed with Phytophthora crown rot. Although $P$. cactorum is the most common species isolated from symptomatic plants, $P$. nicotianae has been recently identified as causing crown rot as well (Marin et al. 2018). These Phytophthora species also infect fruit under certain conditions and cause a fruit rot commonly called leather rot. Unfortunately, the emergence of mefenoxam (Ridomil Gold $\left.{ }^{\circledR}\right)$ resistance has made this disease even more challenging for Florida strawberry.

\section{Causal Agent and Symptoms}

Phytophthora spp. are oomycete plant pathogens that have mycelium with no or few cross walls. They are "fungi-like" organisms but are more closely related to brown algae than fungi. Phytophthora spp. produce asexual zoospores with flagella that allow them to move through water. The disease is characterized by a sudden wilting of plants in fruit production fields (Figure 1). The internal crown of wilting plants shows brown-to-orange necrotic areas when cut open (Figure 2). The wilt and crown rot symptoms of this disease are difficult to distinguish from those produced by Colletotrichum gloeosporioides and Macrophomina phaseolina. Thus, to confirm the causal agent, samples need to be submitted to a diagnostic clinic for isolation and identification of the pathogen.

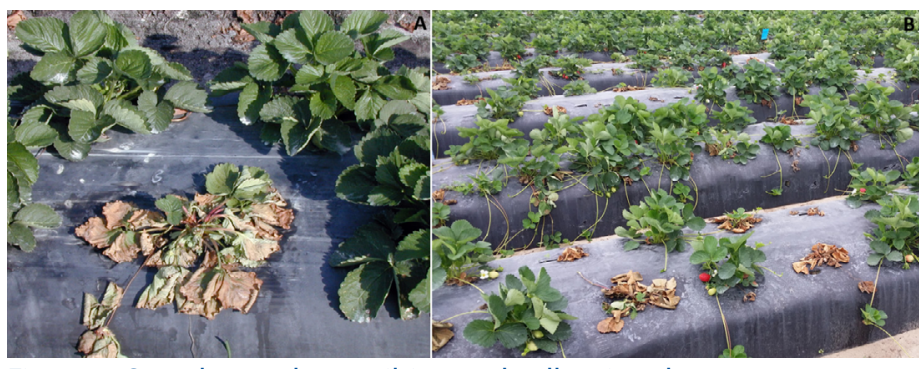

Figure 1. Strawberry plants wilting and collapsing due to Phytophthora crown rot.

Credits: UF/IFAS

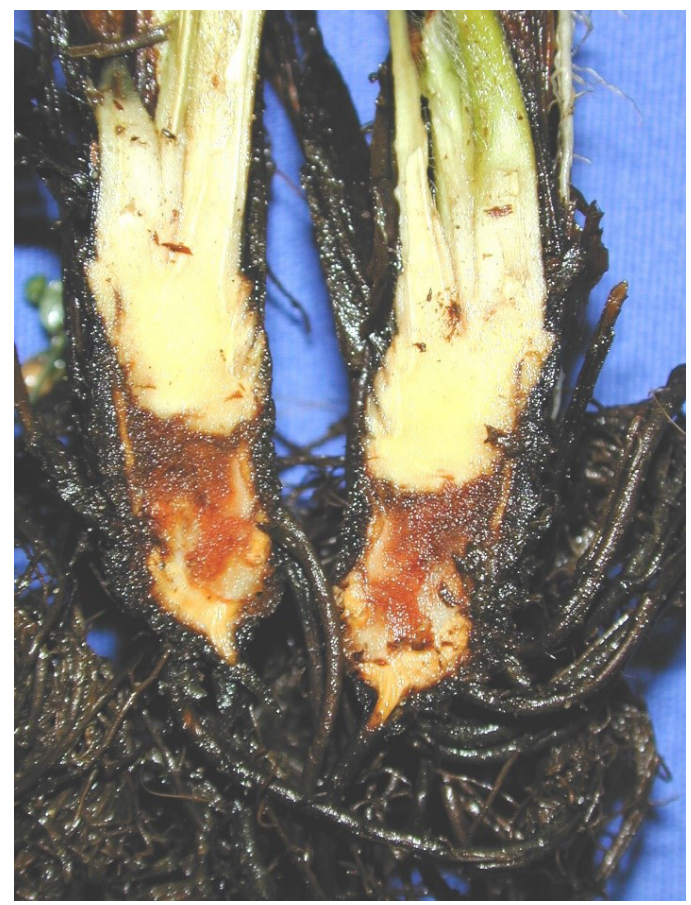

Figure 2. Internal symptoms of Phytophthora crown rot, showing brown-to-orange necrotic areas in the crown.

Credits: UF/IFAS

1. This document is PP350, one of a series of the Plant Pathology Department, UF/IFAS Extension. Original publication date October 2019. Visit the EDIS website at https://edis.ifas.ufl.edu for the currently supported version of this publication.

2. Natalia A. Peres, professor; and Juliana S. Baggio, postdoctoral associate, Plant Pathology Department; UF/IFAS Gulf Coast Research and Education Center, Wimauma, FL 33598.

The Institute of Food and Agricultural Sciences (IFAS) is an Equal Opportunity Institution authorized to provide research, educational information and other services

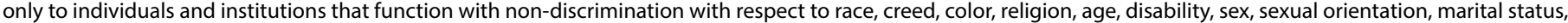

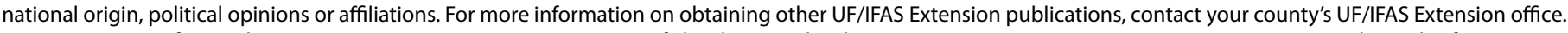
U.S. Department of Agriculture, UF/IFAS Extension Service, University of Florida, IFAS, Florida A \& M University Cooperative Extension Program, and Boards of County Commissioners Cooperating. Nick T. Place, dean for UF/IFAS Extension. 


\section{Disease Development and Spread}

In other pathosystems, Phytophthora species produce oospores that persist in infected soil and plant debris. Although both Phytophthora species affecting strawberry are capable of producing oospores, the pathogen does not survive in the soil over the summer in Florida. Thus, the primary source of inoculum for epidemics in Florida is infected transplants from the nursery. Under wet conditions, the pathogen produces zoospores that "swim" in water to infect additional strawberry plants. Hence, disease outbreaks commonly occur early in the season (October and November) when overhead irrigation, warm temperatures, and rapid juvenile growth favor the disease. However, the disease can also occur during the peaks of fruit production, particularly after high rainfall.

\section{Control}

Management of Phytophthora crown rot involves a combination of cultural and chemical control methods. With the emergence of mefenoxam (Ridomil Gold ${ }^{\circledR}$ ) resistance, alternative management strategies should also be employed.

\section{Cultural}

In Florida, the combination of hot, wet summers and fall fumigation appears to be sufficient to prevent oversummer survival of inoculum. Thus, the best control of Phytophthora crown rot is to use disease-free transplants if available.

Sometimes when plants start to wilt, the grower's first reaction is to increase watering. Because swimming zoospores of Phytophthora move more easily through wet soil, reduced irrigation may slow plant-to-plant spread of the pathogen.

Studies performed at UF/IFAS GCREC have shown that nursery transplants exposed to aerated steam in a closed chamber (i.e., a plant sauna) at $37^{\circ} \mathrm{C}\left(98.6^{\circ} \mathrm{F}\right)$ for 1 hour followed by $44^{\circ} \mathrm{C}\left(111.2^{\circ} \mathrm{F}\right)$ for 4 hours were much less likely to die from Phytophthora crown rot (Figure 3). Therefore, thermotherapy of transplants could be a good alternative for nurseries to manage Phytophthora populations in plant stock.

Cultivars differ greatly in susceptibility to this disease. The old cultivar 'Strawberry Festival' was quite tolerant. However, except for 'Florida Beauty', all currently popular cultivars, such as 'Florida Radiance,' 'FL 127' Sensation ${ }^{\text {тx }}$, and 'Florida Brilliance', are susceptible.

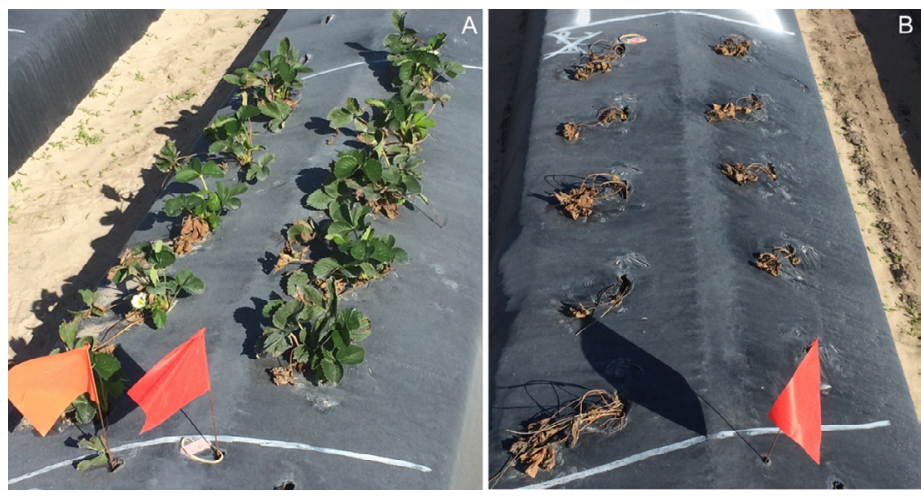

Figure 3. 'Florida $127^{\prime}$ Sensation ${ }^{\mathrm{TM}}$ plants inoculated with a mixture of sensitive and resistant isolates of $P$. cactorum and planted after being steam-treated at $37^{\circ} \mathrm{C}\left(98.6^{\circ} \mathrm{F}\right)$ for 1 hour followed by $44^{\circ} \mathrm{C}\left(111.2^{\circ} \mathrm{F}\right)$ for 4 hours (A), or not steam-treated (B).

Credits: UF/IFAS

\section{Chemical}

In fruit production fields, the disease can be controlled by applications of metalaxyl or mefenoxam (Ridomil Gold ${ }^{\circledR}$ ), or by potassium phosphite products such as Prophyt ${ }^{\circledR}, \mathrm{K}^{-}$Phite ${ }^{\circledR}$, and Fosphite ${ }^{\circledR}$. However, resistance to mefenoxam (Ridomil Gold ${ }^{\circledR}$ ) has emerged, making this disease even more challenging for Florida strawberry. Thus far, resistance has been linked to only a few nursery sources. To confirm resistance to mefenoxam, infected plant samples should be submitted to our diagnostic clinic for testing.

To prevent epidemics in fruiting fields where resistance is not present, mefenoxam and related products containing mefenoxam should be applied through the drip irrigation system immediately after plant establishment. A second application is often made 30 days before the beginning of harvest or at fruit set if disease pressure is high and environmental conditions are favorable. To avoid the development of resistance, these products should not be applied more than 3 times per season. This includes any applications that are made at nurseries.

Fosetyl-aluminum and the phosphite products are considered low-risk for the development of fungicide resistance and should serve as a useful tool for integrated management of Phytophthora crown rot. The phosphite products can be applied by foliar spray or drip injection at 2- to 3-week intervals starting after completion of overhead irrigation for plant establishment. These products should not be tank-mixed with copper fungicides, adjuvants, or foliar fertilizers, because the combination may burn the leaves. 


\section{Literature Cited}

Marin, M. V., T. Seijo, M. S. Oliveira, E. Zuchelli, J. Mertely, and N. A. Peres. 2018. "First Report of Phytophthora nicotianae Causing Crown Rot of Strawberry in the United States." Plant Dis. 102: 1463.

Table 1. Products labeled in Florida for management of Phytophthora crown rot.

\begin{tabular}{|c|c|c|c|c|c|c|}
\hline \multirow[t]{2}{*}{$\begin{array}{l}\text { Product Name } \\
\text { (Active Ingredient) }\end{array}$} & \multirow[t]{2}{*}{$\begin{array}{l}\text { Fungicide } \\
\text { Group }^{a}\end{array}$} & \multicolumn{2}{|c|}{$\begin{array}{c}\text { Maximum Rate Per } \\
\text { Acre Per }\end{array}$} & \multicolumn{2}{|c|}{ Min. Days to } & \multirow[t]{2}{*}{ Remarks } \\
\hline & & Application & Season & Harvest & Reentry & \\
\hline $\begin{array}{l}\text { Metalaxyl 2E AG, MetaStar 2E AG } \\
\text { (Metalaxyl) }\end{array}$ & 4 & $2 \mathrm{qt}$ & $6 \mathrm{qt}$ & 0 & 2 & See label for use in drip irrigation \\
\hline $\begin{array}{l}\text { Ridomil Gold EC, Ridomil Gold SL, } \\
\text { Ultra Flourish (mefenoxam) }\end{array}$ & 4 & $1 \mathrm{pt}$ & $1 \frac{1}{2} \mathrm{qt}$ & 0 & 2 & See label for use in drip irrigation \\
\hline $\begin{array}{l}\text { Alude, Confine Extra, Fosphite, Fungi- } \\
\text { Phite, K-Phite, Phorcephite, Phostrol, } \\
\text { Rampart, } \\
\text { TKO } \\
\text { (many products) }\end{array}$ & 33 & \multicolumn{2}{|c|}{$\begin{array}{l}\text { SEE INDIVIDUAL } \\
\text { LABELS }\end{array}$} & 0 & $4 \mathrm{hr}$ & Do not tank-mix with copper fungicides \\
\hline \multicolumn{7}{|c|}{$\begin{array}{l}\text { a Fungicide group (FRAC Code): Numbers (1-37) and letters }(M) \text { are used to distinguish the fungicide mode of action groups. All fungicides } \\
\text { within the same group (with the same numbers or letter) indicate same active ingredient or similar mode of action. This information must be } \\
\text { considered for the fungicide resistance management decisions } M=\text { Multi-site inhibitors, fungicide resistance risk low. Source: FRAC Code List } \\
2019 ; \text { http://www.frac.info/ } \\
\text { (FRAC = Fungicide Resistance Action Committee). n.a.: not applicable. } \\
\text { Reference: Vegetable Production Handbook of Florida. Available at: http://edis.ifas.ufl.edu/cv292 }\end{array}$} \\
\hline
\end{tabular}

